\title{
Crust and uppermost mantle structure of the Kyushu-Palau Ridge, remnant arc on the Philippine Sea plate
}

\author{
Azusa Nishizawa ${ }^{*}$, Kentaro Kaneda and Mitsuhiro Oikawa
}

\begin{abstract}
We acquired 27 wide-angle seismic profiles to investigate variation in crustal structure along the Kyushu-Palau Ridge (KPR), a 2600-km-long remnant island arc in the center of the Philippine Sea plate; 26 lines were shot across the strike of the KPR at $13^{\circ}-31^{\circ} \mathrm{N}$, and one was shot along the northernmost KPR. The derived P-wave velocity (VP) models show that the KPR has a crustal thickness of 8-23 km, which is thicker than the neighboring backarc basin oceanic crusts of the West Philippine Basin to the west and the Shikoku and Parece Vela Basins to the east. While the KPR crust consists mainly of lower crusts with a Vp of $6.8-7.2 \mathrm{~km} / \mathrm{s}$, the thicker crust contains a thick middle crust with Vp of $6.0-6.8 \mathrm{~km} / \mathrm{s}$. In general, the KPR crust is thicker in the north than in the south. The uppermost mantle velocities just below the KPR bathymetric highs are lower than $8.0 \mathrm{~km} / \mathrm{s}$ and are commonly associated with a slightly high Vp of $7.2 \mathrm{~km} / \mathrm{s}$ at the base of the crust. Large amplitude reflection signals are sometimes observed at far offsets on several lines suggesting the existence of several reflectors at depths of 23-40 km in the mantle beneath the KPR. The characteristics of these reflections are similar to these observed beneath the Izu-Ogasawara (Bonin) island arc, the tectonically conjugate arc of the KPR before backarc basin spreading. Very thin crust and high Pn velocities characterize the transition between the KPR and the eastern basins, which is probably a relic of the initial stage of the rifting. West of the KPR, the crust varies in structure from north to south as a result of the different tectonic settings in which it evolved.
\end{abstract}

Keywords: Kyushu-Palau Ridge, P-wave velocity structure, Paleo-island arc, Initial rifting structure

\section{Background}

The Kyushu-Palau Ridge (KPR) is a 2600-km-long bathymetric high extending north-south at the center of the Philippine Sea plate in the northwestern Pacific (Fig. 1). The KPR is regarded as a remnant of the proto Izu-Ogasawara (Bonin)-Mariana (IBM) island arc that was separated by backarc spreading of the Shikoku and Parece Vela Basins in the late Eocene (e.g., Mrozowski and Hayes 1979; Seno and Maruyama 1984; Okino et al. 1994). Topographic characteristics of the KPR are as follows: large height and width of the KPR in the north than in the south, with the volcanic edifice decreasing in size from north to south; a steep approximately linear slope on the eastern side of the ridge, which was formed by

*Correspondence: azusa@mail1.accsnet.ne.jp

Hydrographic and Oceanographic Department, Japan Coast Guard, Tokyo 135-0064, Japan prior to the backarc spreading of the Shikoku and Parece Vela Basins (e.g., Tokuyama 2007); spar like structures extending westward from the central part of the ridge, which has similar orientations to the seamount chains to the west of the northern Izu-Ogasawara Ridge.

Figure 2 left shows the Bouguer gravity anomaly map. A low anomaly indicating thicker crust correlates with the KPR bathymetric highs. Ishihara and Koda (2007) deduced the crustal thickness of the KPR by threedimensional gravity modeling and showed that the KPR crust has a continuous crustal "root" along the ridge and that the crustal thickness exceeds $15 \mathrm{~km}$ in most of its northern part and $10 \mathrm{~km}$ in most of its southern part. They detected a belt of thin crust with thickness of approximately $5 \mathrm{~km}$ along the transition zone between the Shikoku Basin and KPR. The magnetic anomaly map (Fig. 2 right) shows many dipolar anomalies are distributed along the KPR, and their intensity is larger in the

\section{Springer}

(c) 2016 Nishizawa et al. This article is distributed under the terms of the Creative Commons Attribution 4.0 International License (http://creativecommons.org/licenses/by/4.0/), which permits unrestricted use, distribution, and reproduction in any medium, provided you give appropriate credit to the original author(s) and the source, provide a link to the Creative Commons license, and indicate if changes were made. 


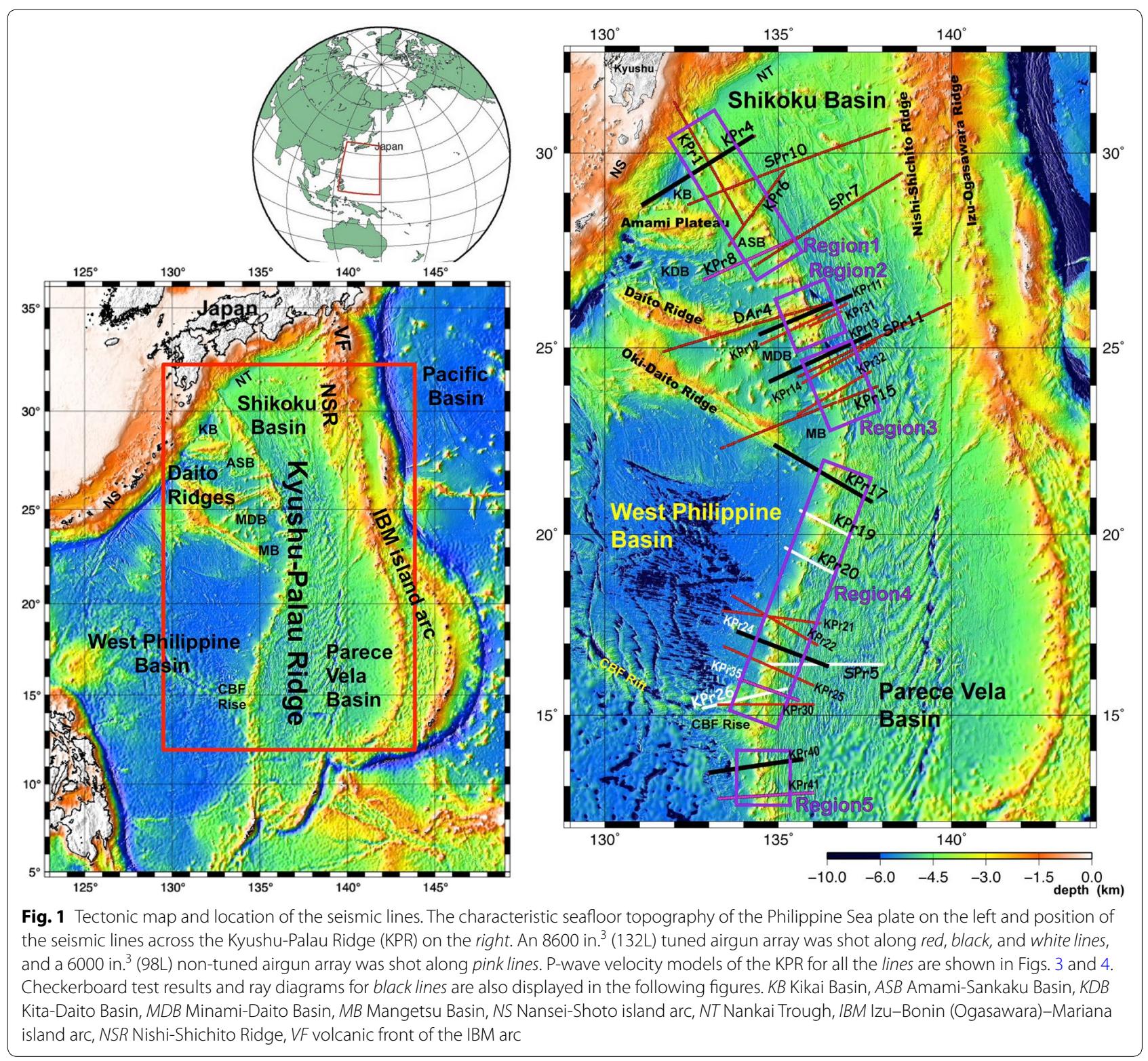

north than in the south. Yamazaki and Yuasa (1998) identified three north-south rows of long-wavelength magnetic anomalies over the KPR, Izu-Ogasawara volcanic front, and Nishi-Shichito Ridge (rear arc of the Izu-Ogasawara arc). They interpreted that these magnetic anomalies reflected magnetization of the deeper crust along the arcs and that the similarity of the three rows of anomalies was due to their separation from a single paleo-Izu-Ogasawara island arc. Ishizuka et al. (2011) investigated in detail the ages and geochemical characteristics of the volcanic rocks sampled from almost the entire length of the KPR. They showed that the KPR was active between 25 and $48 \mathrm{Ma}$, but most of the ages of the volcanic rocks from the KPR lie within the narrow range of 25-28 Ma, and no systematic variation in age can be recognized in along-arc and across-arc directions. However, Eocene ages have only been obtained from the northern half of the KPR, to the north of $23^{\circ} \mathrm{N}$, and a lack of ages older than $32.5 \mathrm{Ma}$ in the southern half could imply that the KPR was established on Cretaceous terranes in the northern region, but on the West Philippine Basin oceanic crust with an age of around 36-46 Ma in the south (Ishizuka et al. 2011; Sasaki et al. 2014).

Many 2-D seismic refraction profiles using ocean bottom seismographs (OBSs) as receivers have been carried out across the Izu-Ogasawara island arc and the KPR. 


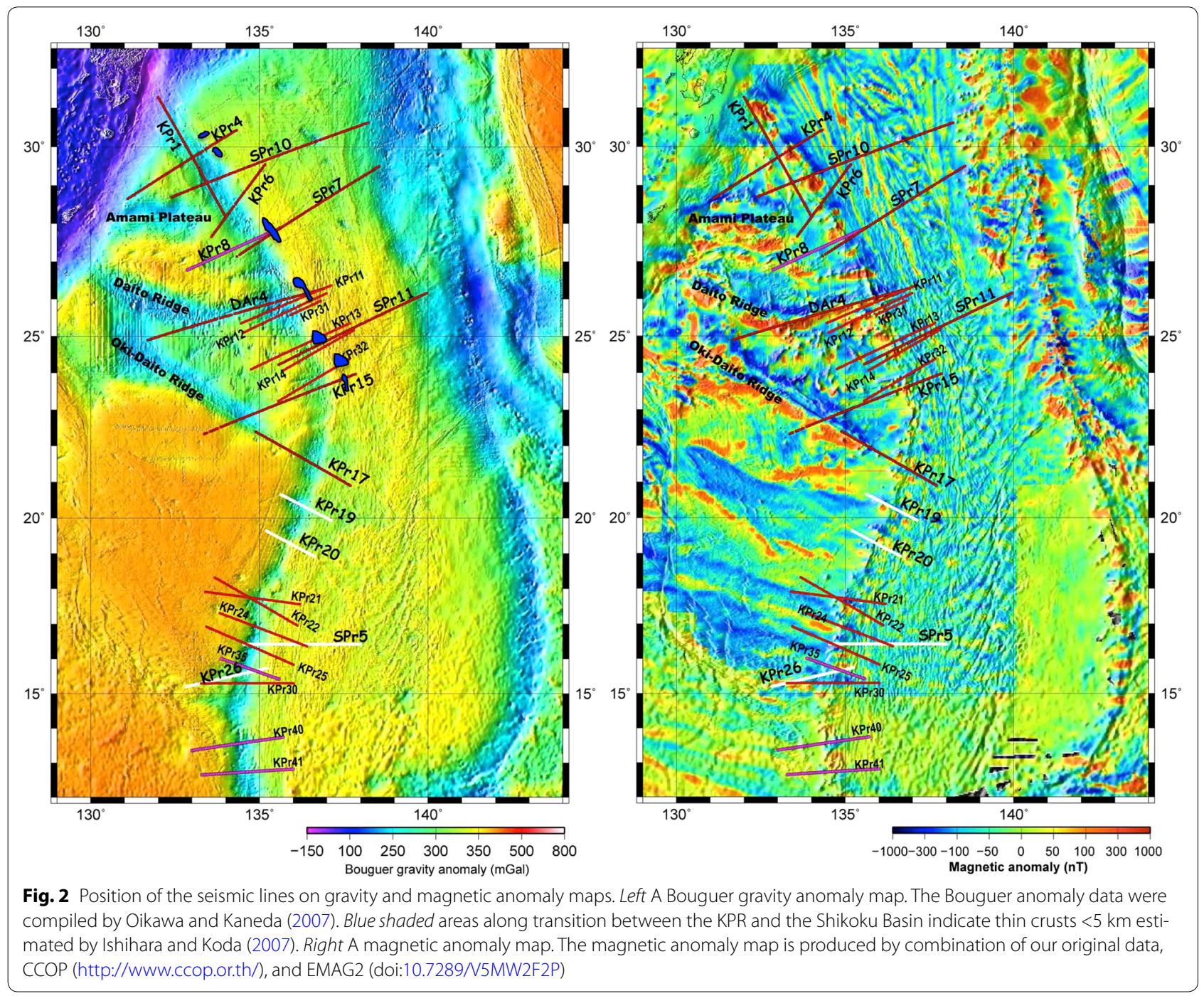

The first good quality seismic experiment across the Izu-Ogasawara island arc was acquired at $32^{\circ} 15^{\prime} \mathrm{N}$ in the northern part of the arc in 1995, and a P-wave velocity $(\mathrm{Vp})$ model down to the Moho was obtained (Suyehiro et al. 1996). A Vp model of the arc at around $30^{\circ} 30^{\prime}$ $\mathrm{N}$ was also presented by Nishizawa et al. (2006), showing that there is no significant variation in the arc crustal models between $30^{\circ} 30^{\prime}$ and $32^{\circ} 15^{\prime} \mathrm{N}$, with both models characterized by a middle crust with a $\mathrm{Vp}$ of $6 \mathrm{~km} / \mathrm{s}$, a lower crust of $6.8-7.3 \mathrm{~km} / \mathrm{s}$, and a total thickness of around $20 \mathrm{~km}$. However, extensive seismic refraction and reflection surveys conducted under Japanese Continental Shelf Survey (CSS) Project in 2004-2008 showed large variations in crustal models over large distances along the Izu-Ogasawara arc from north to south. For instance, Kodaira et al. (2007b) presented a $>1000-\mathrm{km}$ long wide-angle seismic profile along the volcanic arc, revealing two scales of variation in arc crust beneath the volcanic front; at one scale the Izu arc north of $30^{\circ} \mathrm{N}$ is much thicker than the Ogasawara arc in the south; at the intervolcano scale of around $50 \mathrm{~km}$, the crust is thicker below each volcano. A seismic study along the rear arc of the Izu arc (Kodaira et al. 2008) also shows marked variations in crustal thickness that are attributed mainly to thickness variations of the middle crustal layer with $\mathrm{Vp}$ of $6.0-6.8 \mathrm{~km} / \mathrm{s}$. Kodaira et al. (2008) proposed that the rear-arc crust is composed of a remnant-arc crust that was separated from the volcanic front, probably in the Oligocene, and that most of the rear-arc crust was created before separation from the volcanic front.

Tonalitic rocks dredged from the KomahashiDaini Seamount (on line KPr4 in Fig. 5), the shallowest seamount in the northern KPR, which are dated at 37-38 Ma, were formed during early stage of the 
Izu-Ogasawara-Mariana (IBM) arc volcanism (Haraguchi et al. 2003). The tonalite complex seems to correspond to this middle crust of the intra-oceanic island arcs with $\mathrm{Vp}$ of around $6 \mathrm{~km} / \mathrm{s}$. Distribution of the middle crust along the ridge axis could provide a fundamental insight into an evolution of the proto-IBM arc.

As mentioned before, the Kyushu-Palau and IzuOgasawara Ridges were originally a single intra-oceanic arc produced by subduction of the Pacific plate beneath the Philippine Sea plate. However, the crustal structure of the KPR appears to be different from that of Izu-Ogasawara island arc, since the KPR was less affected by subduction-related volcanism after initiation of the backarc spreading. Therefore, comparison of the crustal structure of the KPR and Izu-Ogasawara arc can help constrain the early evolution of the Izu-Ogasawara arc system.

Recently, the Daito Ridges, other significant bathymetric highs characterizing the Philippine Sea plate, were comprehensively investigated geologically and geophysically under the CSS Project in Japan (e.g., Ishizuka et al. 2013; Nishizawa et al. 2014). Three large bathymetric highs, the Amami Plateau, the Daito Ridge, and the OkiDaito Ridge, from north to south (Fig. 1) are also originated from paleo-island arcs. Nishizawa et al. (2014) showed that these bathymetric highs usually have a middle crust with a $\mathrm{Vp}$ of $6.3-6.8 \mathrm{~km} / \mathrm{s}$, a lower crust with $\mathrm{Vp}=6.8-7.2 \mathrm{~km} / \mathrm{s}$, a Pn velocity of 7.6-7.8 km/s, and a crustal thickness of $15-25 \mathrm{~km}$. These structures are similar to those of the IBM island arc, which are immature paleo-island arcs.

Several seismic refraction experiments were previously carried out over the KPR (e.g., Murauchi et al. 1968; Shinohara et al. 1999; Arisaka et al. 2003). However, these velocity models are too sparsely distributed to understand all the characteristics of the KPR crust along the entire length. In 2004-2008, the CSS Project also designed a massive seismic survey of the KPR region. We conducted 27 seismic reflection and refraction lines across the KPR between $13^{\circ}$ and $31^{\circ} \mathrm{N}$ and one line along the ridge in the northernmost part. Using these survey data, Nishizawa et al. (2007) presented four Vp models for the KPR crusts at $15^{\circ}-21^{\circ} \mathrm{N}$ and showed that thicker crust exists beneath the KPR than the adjacent backarc basin oceanic crusts of the West Philippine Basin and Parece Vela Basin. Kaneda et al. (2015) presented an overview on most of the seismic refraction results obtained by Japan Coast Guard under the CSS Project. References including basic information of the surveys and data were provided in Kaneda et al. (2015) by citation of the open cruise reports. Thier scientific results from the KPR region, however, were only briefly summarized. The purpose of this paper is to compile all the KPR seismic structural models including the above results and to characterize in detail the variation of the KPR Vp models along the ridge axis, which will provide key information for the construction of evolution model of the Philippine Sea plate involving the KPR.

\section{Methods}

The seismic survey consisted of 27 lines which were located to sample well the variations in seafloor topography of the KPR from $13^{\circ}$ to $31^{\circ} \mathrm{N}$. Because the row of the KPR bathymetric highs is curved and the ridge width is thin compared with the Izu-Ogasawara arc, it is difficult to design an along-ridge seismic line. Therefore, 26 of the 27 seismic lines cross the KPR strike almost perpendicularly and only one line was shot along the ridge at the northern end of the KPR. The line lengths range from $105 \mathrm{~km}$ for KPr31 to $610 \mathrm{~km}$ for SPr10 (Fig. 1).

We deployed OBSs as a receiver at an average interval of $5 \mathrm{~km}$ along each line. Each OBS is equipped with a three-component $4.5 \mathrm{~Hz}$ geophone and a hydrophone. A tuned airgun array of 36 airguns with a total volume of 8040 cubic inches $(132 \mathrm{~L})$ or a non-tuned airgun array of 4 airguns with a total volume of 6000 cubic inches $(98 \mathrm{~L}$ ) was shot at an interval of $200 \mathrm{~m}$ (90 s) for the wide-angle seismic profiles. Multichannel seismic (MCS) reflection data using a $480 \mathrm{ch}$. (6000 m long) or $240 \mathrm{ch}$. (3000 m) hydrophone streamer were also collected on the coincident lines. The airgun array was shot at a 50-m interval for each MCS line. Navigation was provided by the ship's Global Positioning System, and each OBS instrument was relocated using the direct water wave arrivals (Oshida et al. 2008).

The procedures of the OBS data processing and velocity analysis are the same as presented by Nishizawa et al. (2014). That is, the OBS record sections from threecomponent geophone and hydrophone outputs were produced through frequency filtering, deconvolution, and a slant stack to increase the signal-to-noise ratio. Travel times of the reflection and refraction signals were picked from these record sections and used to construct a P-wave velocity model. We introduced the thickness of the top most sedimentary layer constrained by MCS data into the initial velocity model for each line. Then, we obtained velocity models using the tomo2d tomographic inversion coded of Korenaga et al. (2000), forward modeling with two-dimensional ray tracing (Fujie et al. 2000; Kubota et al. 2009) and comparison with synthetic seismograms calculated by a finite difference method, E3D (Larsen and Schultz 1995). The horizontal grid size of the tomographic inversion is $0.5 \mathrm{~km}$ in all the velocity models, and the vertical grid size gradually increased with depth according to the relation $0.05+(0.01 \times$ depth $(\mathrm{km}))^{1 / 2} \mathrm{~km}$. Almost all velocity models have tomographic inversion misfits less than $50 \mathrm{~ms}$. We examined 
the resolving power of the results using conventional checkerboard resolution tests and checked ray coverage for each model. Although the forward modeling was time-consuming, the method was very useful to interpret weak and distant refraction signals and intermittent reflection signals. We estimated the deeper structure at depths greater than $15 \mathrm{~km}$ mainly by forward modeling, since the ray coverage in the deeper part was usually very low.

\section{Results}

Figures 3 and 4 show all the P-wave velocity models across the KPR and demonstrate the variation along the ridge axis from north to south. We split the KPR into five regions shown in Fig. 1 and describe in detail representative profiles for each region. We loosely divide our crustal models into three parts (upper, middle, and lower crust) based on their P-wave velocities, velocity gradients, and thickness proportions following Calvert (2011) and Nishizawa et al. (2014) and will describe their characteristics below.

\section{Region 1}

We show the Vp model for KPr4 (Fig. 5), which is representative of the northernmost region of the KPR where the bathymetric highs are very shallow and wide. The shallowest portion along KPr4 corresponds to Komahashi-Daini Seamount.

Tomographic inversion misfit is less than $50 \mathrm{~ms}$, and the checkerboard test result and ray diagram (Fig. 5 bottom) show the model shallower than $15 \mathrm{~km}$ is reliable. The Vp model of Komahashi-Daini Seamount has a thick middle crust with a thickness of around $7 \mathrm{~km}$ and $\mathrm{Vp}$ of $6-6.5 \mathrm{~km} / \mathrm{s}$. Since the region below $15 \mathrm{~km}$ depth is less resolvable, and the crustal thickness beneath the seamount is $18 \mathrm{~km}$, the $\mathrm{Vp}$ at the bottom of lower crust of $7.1 \mathrm{~km} / \mathrm{s}$ and $P n$ velocity of $7.6 \mathrm{~km} / \mathrm{s}$ were estimated by two-dimensional ray tracing. The transition region between the Shikoku Basin and the KPR is characterized by thin crust less than $5 \mathrm{~km}$ thick excluding the topmost sediment layer and a high Pn (uppermost mantle) velocity of $8.1-8.2 \mathrm{~km} / \mathrm{s}$ (Fig. 5). On the other hand, a small bathymetric high exists to the west of Komahashi-Daini Seamount at a distance of $200 \mathrm{~km}$, and it has a slightly thicker curst with no thick middle crust layer. A thick sediment layer with $\mathrm{Vp}$ smaller than $3.5 \mathrm{~km} / \mathrm{s}$ and with a maximum thickness of around $3 \mathrm{~km}$ exists between Komahashi-Daini Seamount and the small bathymetric high. Deeper Moho at the southwestern end of the Vp model indicates a subducting bathymetric high beneath the forearc of the Nansei-Shoto island arc.

The total thicknesses of the KPR crusts are appreciably greater than those of the Shikoku Basin for all the lines of
KPr4, SPr10, KPr6, KPr8, and SPr7 in Region 1 (Fig. 3). Particularly thick middle crust was found also for SPr10 and KPr6, and slightly thin middle crusts are estimated for KPr8 and SPr7 where the widths of the ridge topography are narrower than those of the northern lines.

It is notable that thin crust occurs at the boundary of the KPR and Shikoku Basin on all lines and is less than $3 \mathrm{~km}$ thick on line KPr8 (Fig. 3). Pn velocities in this area are higher than $8.0 \mathrm{~km} / \mathrm{s}$, which are significantly higher than those of the Shikoku Basin. To the west of the KPR, the upper sedimentary layer is relatively thick.

\section{Region 2}

Four lines DAr4, KPr11, KPr12, and KPr31 were located to cross the region where the KPR lies close to several seamounts and areas of shallow seafloor the west of the KPR.

We show the result for KPr11 in Fig. 6 as a representative in this region. KPr11 was positioned around $10 \mathrm{~km}$ south of DAr4 which connects to the Daito Ridge to the west. The Vp model beneath the KPR for KPr11 shows a total crustal thickness of around $13 \mathrm{~km}$, a middle crust thickness of about $5 \mathrm{~km}, \mathrm{Vp}$ at the bottom of lower crust of $7.2 \mathrm{~km} / \mathrm{s}$, and Pn velocity of $7.6 \mathrm{~km} / \mathrm{s}$. Slightly shallow Moho at a distance of $140 \mathrm{~km}$ is required to explain observed PmP arrivals. The eastern transition zone from the KPR to the Shikoku Basin is characterized by abrupt crustal thinning to less than $5 \mathrm{~km}$. At the western transition, around 20-km-thick KPR crust thins to $10 \mathrm{~km}$ beneath the Minami-Daito Basin. We detected a very fast Pn velocity of $8.3 \mathrm{~km} / \mathrm{s}$ at this transition.

Similar Vp models were obtained for DAr4, KPr12, and KPr31 (Fig. 3). The boundary between the KPR and the Shikoku Basin is again characterized by very thin crust of 3 to $5 \mathrm{~km}$ and Pn velocities of $8.0-8.1 \mathrm{~km}$, which are different from values found generally in the Shikoku Basin. On the other hand, the Minami-Daito Basin has thick crust of around $10 \mathrm{~km}$ and high Pn velocity of 8.1$8.3 \mathrm{~km} / \mathrm{s}$, which is notably different from a typical oceanic crust. The crustal thickness in the western transition to the Minami-Daito Basin is not thinner than that of the Minami-Daito Basin, in general.

\section{Region 3}

Region 3 corresponds the area where the eastern edge of the KPR bounds the deepest part of the Shikoku Basin and the KPR topography is slightly deeper and narrower than in other regions. We shot five lines including KPr13, SPr11, KPr14, KPr32, and KPr15 in this region and compiled each Vp model in Fig. 3.

We show the Vp model for KPr13 in Fig. 7. The crustal thickness beneath the KPR is about $10 \mathrm{~km}$ with a middle crust of $2 \mathrm{~km}$. Vp at the bottom of the lower crust and 


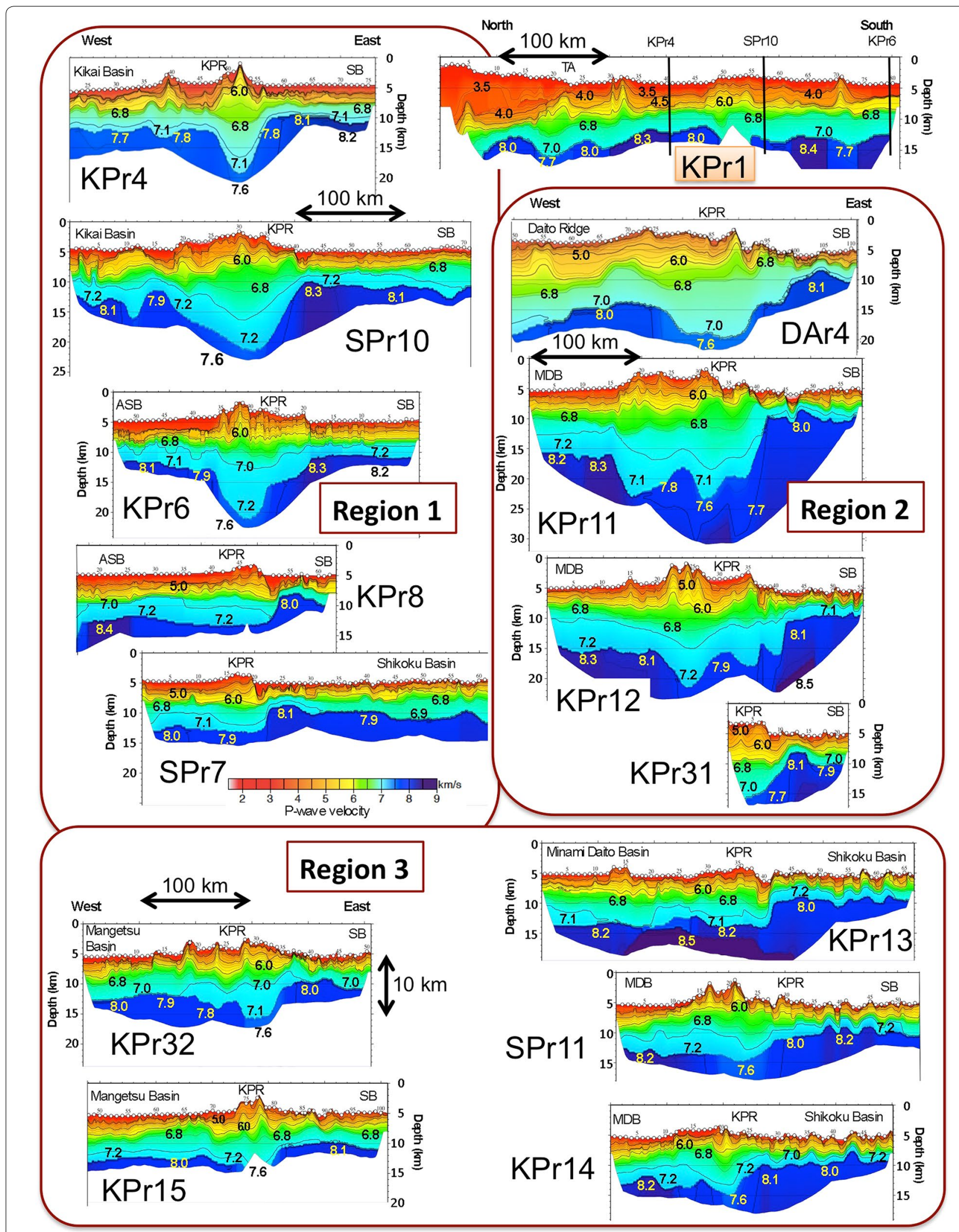

Fig. 3 P-wave velocity models in the northern part of the KPR. All the models are shown in the same scale. TA trench axis, SB Shikoku Basin, ASB Amami-Sankaku Basin, KB Kikai Basin, MDB Minami-Daito Basin 

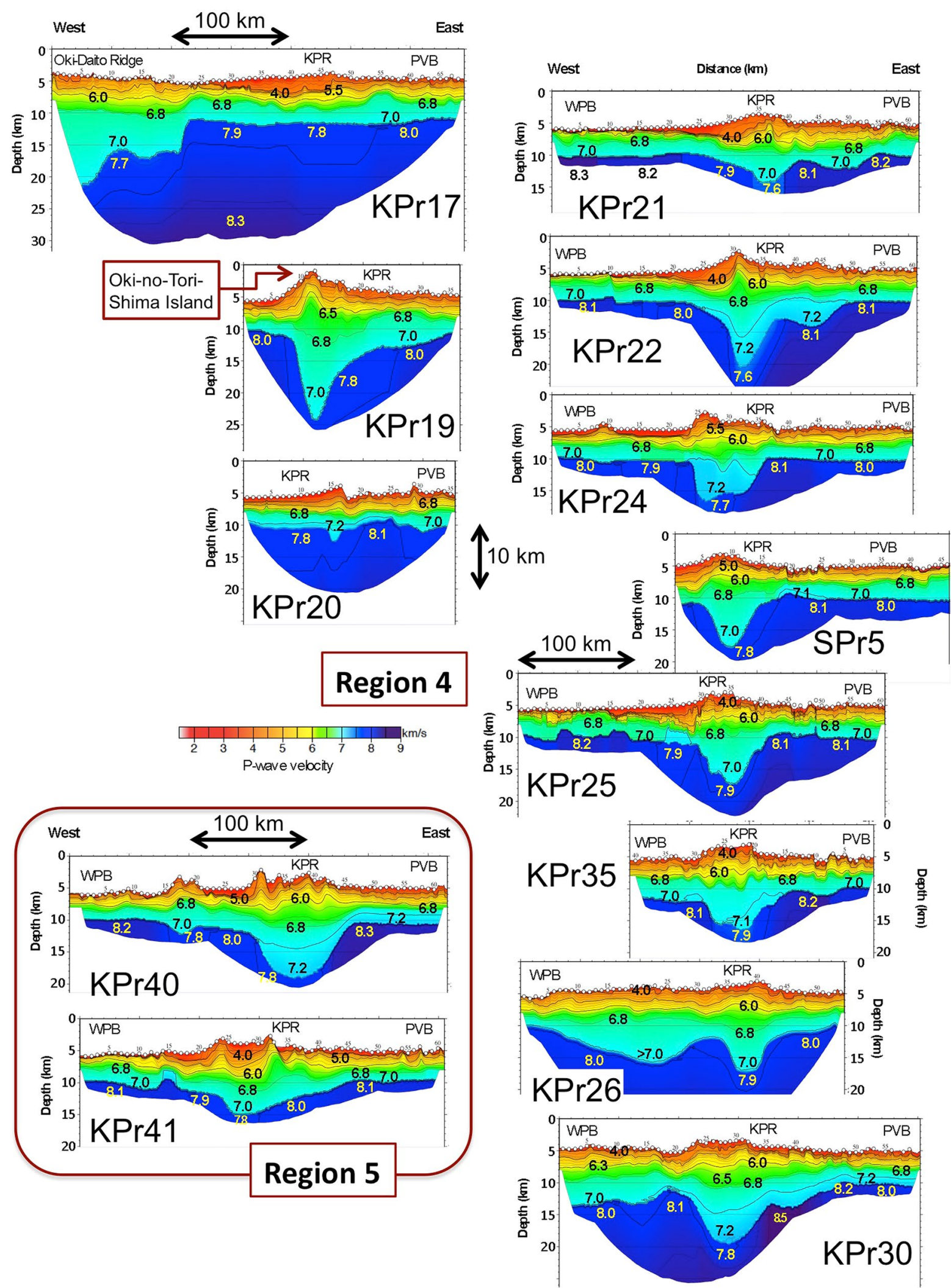

Fig. 4 P-wave velocity models in the central and southern parts of the KPR. All the models are shown in the same scale. PVB Parece Vela Basin, WPB West Pacific Basin 


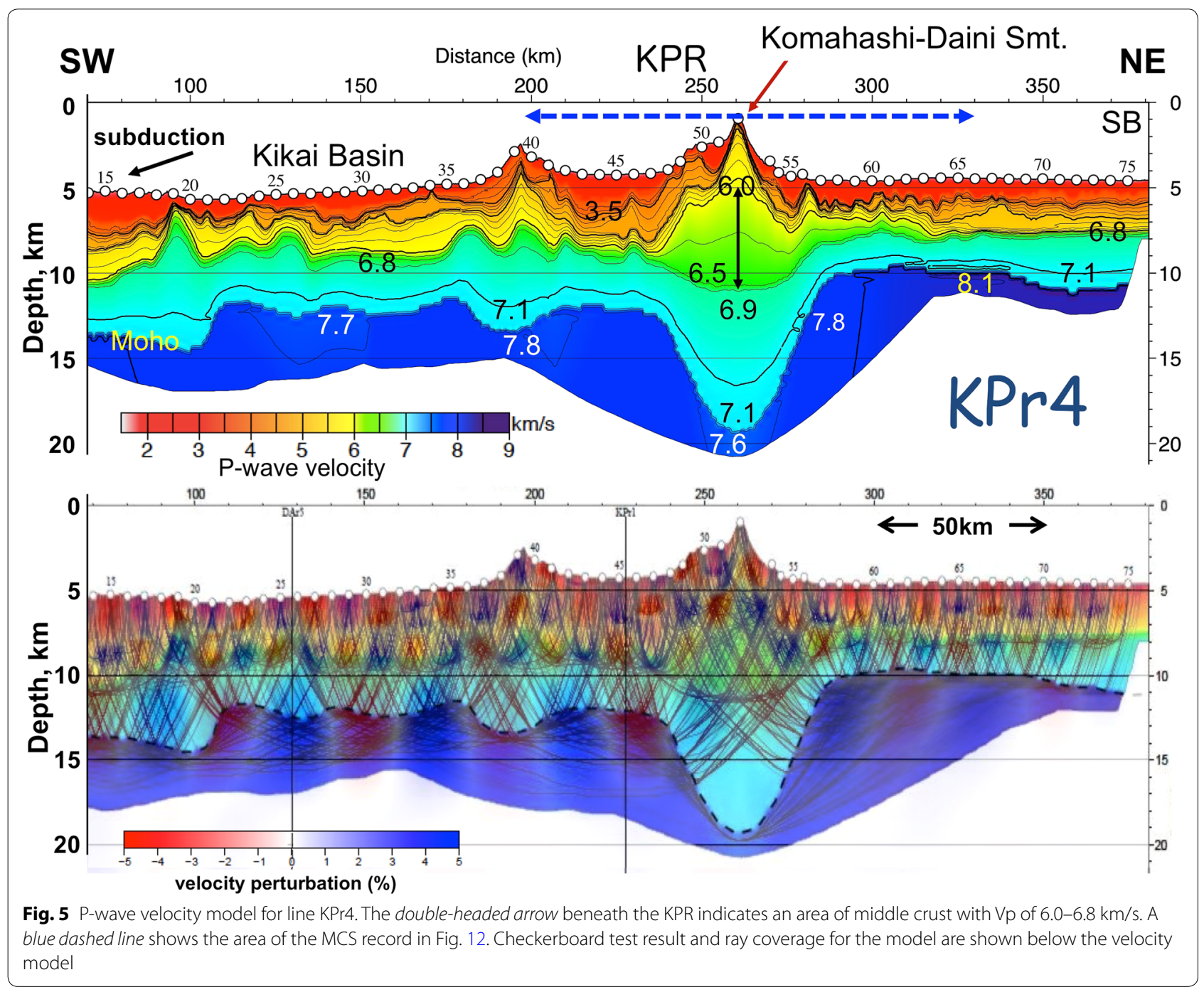

the Pn velocity are 7.2 and $8.2 \mathrm{~km} / \mathrm{s}$, respectively. The Pn velocity beneath the KPR is very high, over $8.2 \mathrm{~km} / \mathrm{s}$, much different from other lines. Since this line has a thin crust of less than $10 \mathrm{~km}$ as a whole, the checkerboard test result in Fig. 7 bottom shows good recovery. We could confirm the high Pn velocity and thin crust not only by the tomographic inversion but also by 2-D forward raytracing method.

Common characteristics among the five lines are follows: Crustal thickness below the KPR is more than $10 \mathrm{~km}$, but less than $5 \mathrm{~km}$ beneath the eastern transition into the Shikoku Basin. To the west of the KPR, the crustal thicknesses of the Minami-Daito Basin on lines KPr13, SPr11, and KPr14 and of the Mangetsu Basin on lines KPr32 and KPr15 are larger than in the Shikoku Basin. The crust of the Minami-Daito Basin is slightly thinner in Region 3 than in Region 2. Uppermost mantle velocities for the lines other than KPr13 beneath the KPR were estimated to be $7.6-7.8 \mathrm{~km} / \mathrm{s}$, while Pn velocities beneath the Minami-Daito and Mangetsu Basins are 8.2 and $8.0 \mathrm{~km} / \mathrm{s}$, respectively.

\section{Region 4}

Region 4 corresponds to be the central part of the KPR where the KPR is basically bounded by the Parece Vela Basin (PVB) to the east and by the West Philippine Basin to the west. There are 11 seismic lines across the KPR from $22^{\circ} \mathrm{N}$ to $15^{\circ} \mathrm{N}$, and the $\mathrm{Vp}$ models are shown in Fig. 4. Since the previous paper by Nishizawa et al. (2007) has already reported velocity models for KPr19, Kpr20, Spr5, and KPr26 (white lines in Fig. 1 right), we will highlight the result for KPr24 in Region 4 (Fig. 8). The seafloor topography to the west of the KPR is flat, $5000 \mathrm{~m}$ deep, but a rather rugged seafloor fabric with N-S strike characterizes PVB to the east of the KPR. As shown in the checkerboard test result (Fig. 8 bottom), it is difficult 


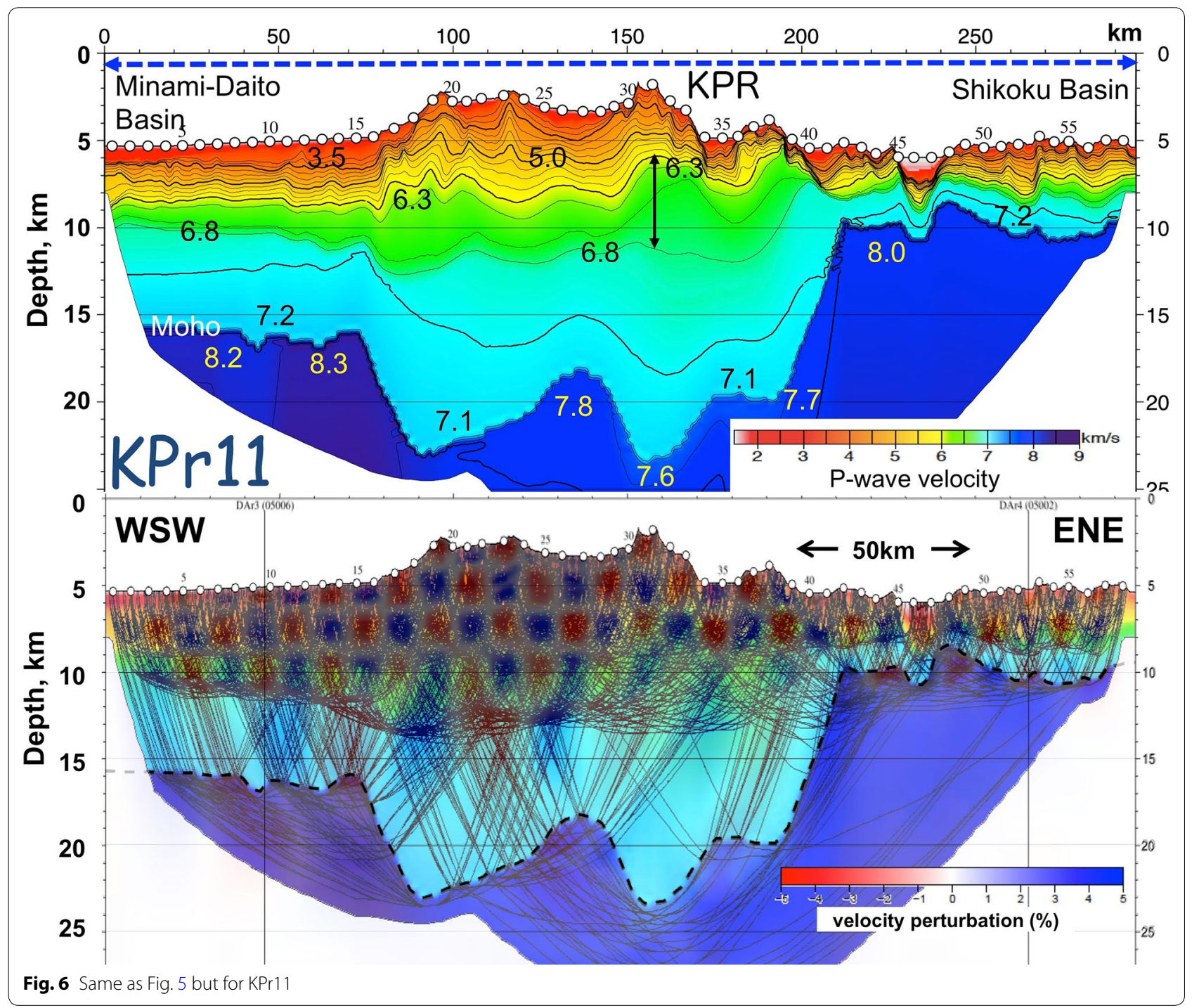

to determine deeper structure beneath the KPR from the tomographic inversion. Thus, we inferred velocities in the lower crust and uppermost mantle by trial-and-error fitting of observed distant travel times using the forward modeling. Vp model for KPr24 has a middle crust with thickness of $4.5 \mathrm{~km}$ and a total crustal thickness of $14 \mathrm{~km}$. The P-wave velocities at the base of the crust and in the uppermost mantle are estimated to be 7.2 and $7.7 \mathrm{~km} / \mathrm{s}$, respectively.

We observed large amplitude reflection signals at far offsets in several OBS records on KPr24. Figure 9 shows an example of the record section obtained at OBS 43 in the PVB. The signals in red ellipses in Fig. 9a were mapped to a black curve with white arrows at depth of $25 \mathrm{~km}$ in Fig. 9c using the travel time mapping method by Fujie et al. (2006). The other black curves correspond to the mapping results from reflection signals recorded by other OBSs. Although similar signals with large amplitudes at far offsets were also observed on lines KPr21 and KPr22, their appearances, that is, their travel times and offsets from the KPR are different. Furthermore, such signals were not observed on line KPr25.

KPr17 is located from the southeastward extension of the Oki-Daito Ridge to the PVB in the east (Fig. 1). The Vp model (Fig. 10) is distinctive compared with other KPR models; that is, the total crustal thickness beneath the KPR is only around $8 \mathrm{~km}$ including the thick top sedimentary layer with $\mathrm{Vp}$ less than $4 \mathrm{~km} / \mathrm{s}$ and with a thickness of about $3 \mathrm{~km}$. The thin total crustal thickness is due to an anomalously thin lower curst. However, the KPR Pn velocity of $7.8 \mathrm{~km} / \mathrm{s}$ is well constrained as shown in the checkerboard result (Fig. 10 bottom), which is similar to other KPR models. Large amplitude reflection signals were recorded on many record sections over 


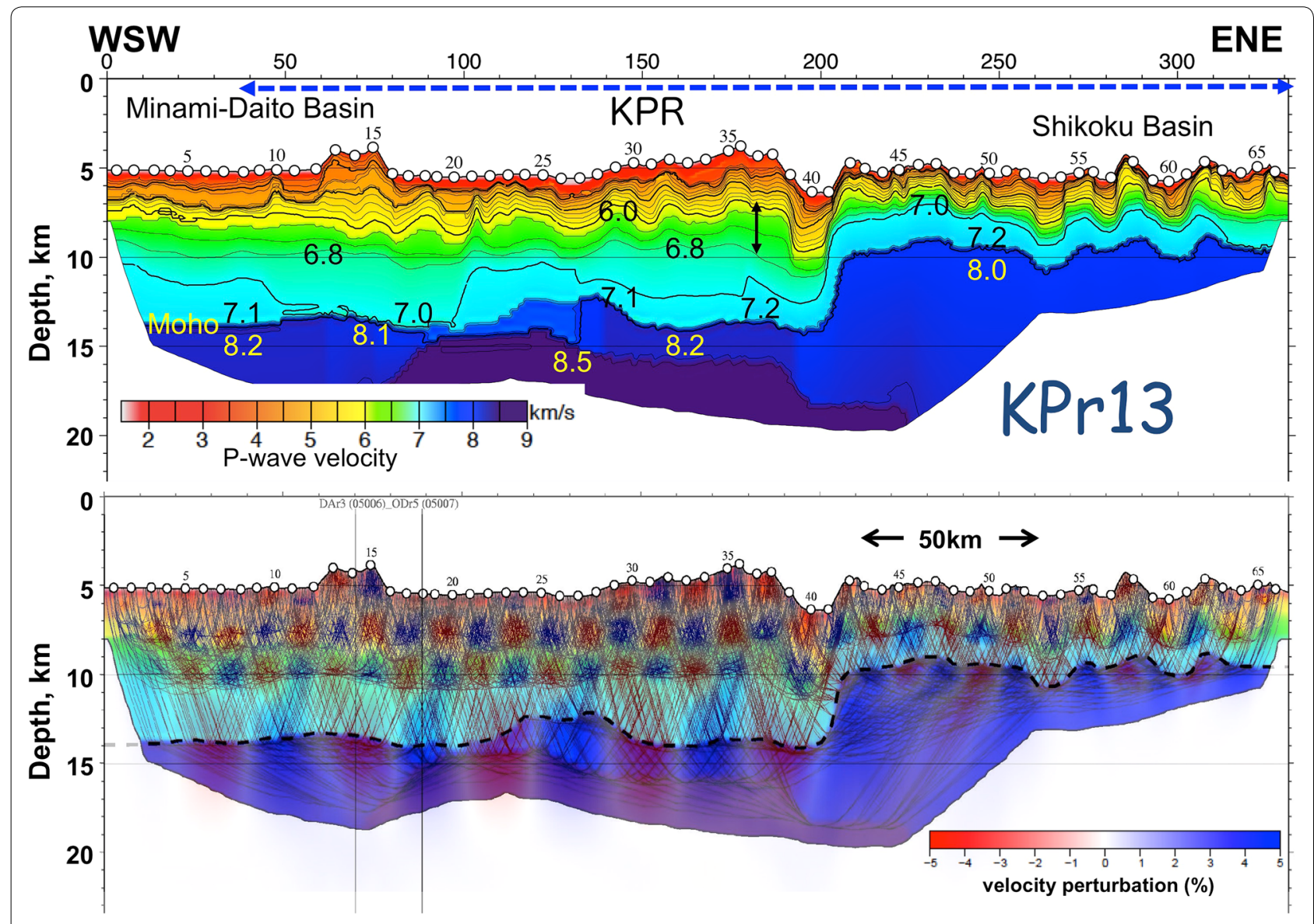

Fig. 7 Same as Fig. 5 but for KPr13

offsets of around $80 \mathrm{~km}$ along KPr17. Assuming a Vp below the Moho of roughly $8.0 \mathrm{~km} / \mathrm{s}$, the travel times of these signals can be explained by reflectors at $10-14 \mathrm{~km}$ below the Moho under the Oki-Daito Ridge and KPR at distances of $40-160 \mathrm{~km}$ and of $200-250 \mathrm{~km}$. These reflectors are much deeper compared with those below KPr24.

The KPR Vp models in Region 4 (Fig. 4) differ from line to line, but there are some common features: thicker crust and especially middle crust than in the adjacent basins, Pn velocities less than $8.0 \mathrm{~km} / \mathrm{s}$, thin crust and high $\mathrm{Pn}$ velocities over $8.0 \mathrm{~km} / \mathrm{s}$ at the eastern boundary with the PVB.

\section{Region 5}

Lines KPr40 and KPr41 are situated to the south of the intersection between the CBF Rise and KPR, and the southernmost profiles in this study. On line KPr40, the Vp model beneath KPR reveals that the middle crust is about $5 \mathrm{~km}$ thick and the $\mathrm{Vp}$ at the bottom of the lower crust is $7.2 \mathrm{~km} / \mathrm{s}$. The total crustal thickness is $15 \mathrm{~km}$, and Pn velocity is $7.8 \mathrm{~km} / \mathrm{s}$ (Fig. 11). The model for KPr41 shows slightly thinner crust and slower $\mathrm{Vp}$ at the bottom of the crust compared with the KPr40 (Figs. 4, 11).

\section{Discussion}

\section{P-wave velocity structure of the KPR}

Although the velocity variation is large, we can derive some common characteristics of the KPR by comparing the Vp models along the KPR. The Vp models show the KPR has thicker curst with thicknesses of $8 \mathrm{~km}$ (KPr 17 and KPr20) to $23 \mathrm{~km}$ (KPr19), compared with standard oceanic crusts of $7.1 \mathrm{~km}+-0.8 \mathrm{~km}$ (e.g., White et al. 1992), and also lower Pn velocities less than $8.0 \mathrm{~km} / \mathrm{s}$. When we compare the KPR models with the neighboring backarc basin oceanic crust of the West Philippine Basin (Arisaka et al. 2003) to the west and of the Shikoku and Parece Vela Basins to the east (e.g., Nishizawa et al. 2007, 2011), the KPR crust is always thicker (Figs. 3, 4). The thick KPR crust is mainly composed of lower crust with $\mathrm{Vp}$ of $6.8-7.2 \mathrm{~km} / \mathrm{s}$ (Figs. 3, 4). Crust thicker than $18 \mathrm{~km}$ also has over $5 \mathrm{~km}$ of middle crust with Vp of 6.0 to $6.8 \mathrm{~km} / \mathrm{s}$. For example, the middle crust beneath $\mathrm{KPr} 4$, SPr10, and KPr19 is thicker than $6 \mathrm{~km}$. Pn velocities 


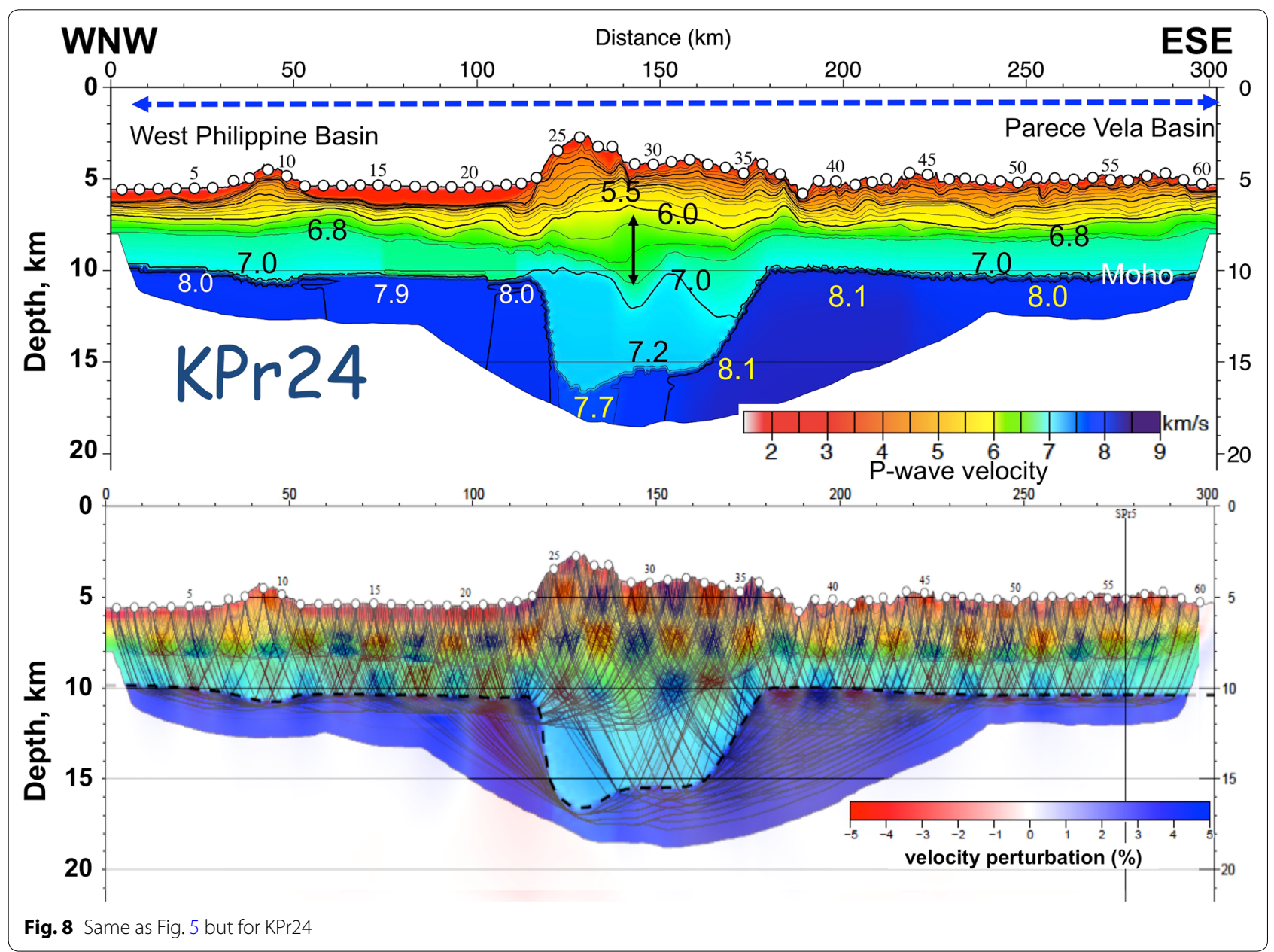

just below the KPR are less than $8.0 \mathrm{~km} / \mathrm{s}$ for almost all seismic lines, often accompanying a slightly high $\mathrm{Vp}$ of $7.2 \mathrm{~km} / \mathrm{s}$ at the base of the crust. The lower Pn and higher crust bottom velocities were also found beneath the paleo-island arcs at the Daito Ridge region (Nishizawa et al. 2014) and Izu-Ogasawara intra-oceanic arc (e.g., Suyehiro et al. 1996).

An exception to the thicker KPR crust is found on line KPr17 as shown in Fig. 10. Usually, we can estimate crustal thicknesses from Bouguer gravity anomaly distribution. Smaller values of Bouguer gravity anomaly along the KPR in Fig. 2 left roughly coincide the regions with thick crusts. However, the low gravity anomaly below the KPR along KPr17 is mainly caused by thick low velocity materials with $\mathrm{Vp}<4 \mathrm{~km} / \mathrm{s}$ and thickness of around $3 \mathrm{~km}$. Although the origin of the thick materials is unknown, the lower Pn velocity of $7.8 \mathrm{~km} / \mathrm{s}$ beneath the ridge seems to be similar to the KPR in general.

When we could record S-wave signals occasionally converted from P-wave at the base of the top sedimentary layer, we tried 2-D forward modeling to estimate preliminary values of $\mathrm{Vp} / \mathrm{Vs}$. The results show that $\mathrm{Vp} /$ Vs for the uppermost mantle beneath the KPR is around 1.73 , and not larger than 1.8. Therefore, we infer that the mantle serpentinization is probably not responsible for the low uppermost mantle velocities.

The crustal structure of the Izu-Ogasawara intraoceanic arc, the tectonically conjugate island arc of the KPR, was well investigated also by the CSS project of Japan (e.g., Kodaira et al. 2007b, 2008). In the rear arc (Nishi-Shichito Ridge) area of the Izu-Ogasawara arc, Kodaira et al. (2008) showed that the thick middle crust contributes to the total crustal thicknesses. Kodaira et al. (2007a) also focused on the distribution of the middle crust in the Vp model along the volcanic front in the Izu arc, where is characterized by bimodal volcanism. They found that basaltic volcanoes have thick middle crust and rhyolitic volcanoes thinner middle crust and deduced that continental crust grows predominantly below the basaltic volcanoes in the Izu arc. Furthermore, they revealed that the thicker middle crust below the volcanic front and rear arc correspond to the high 


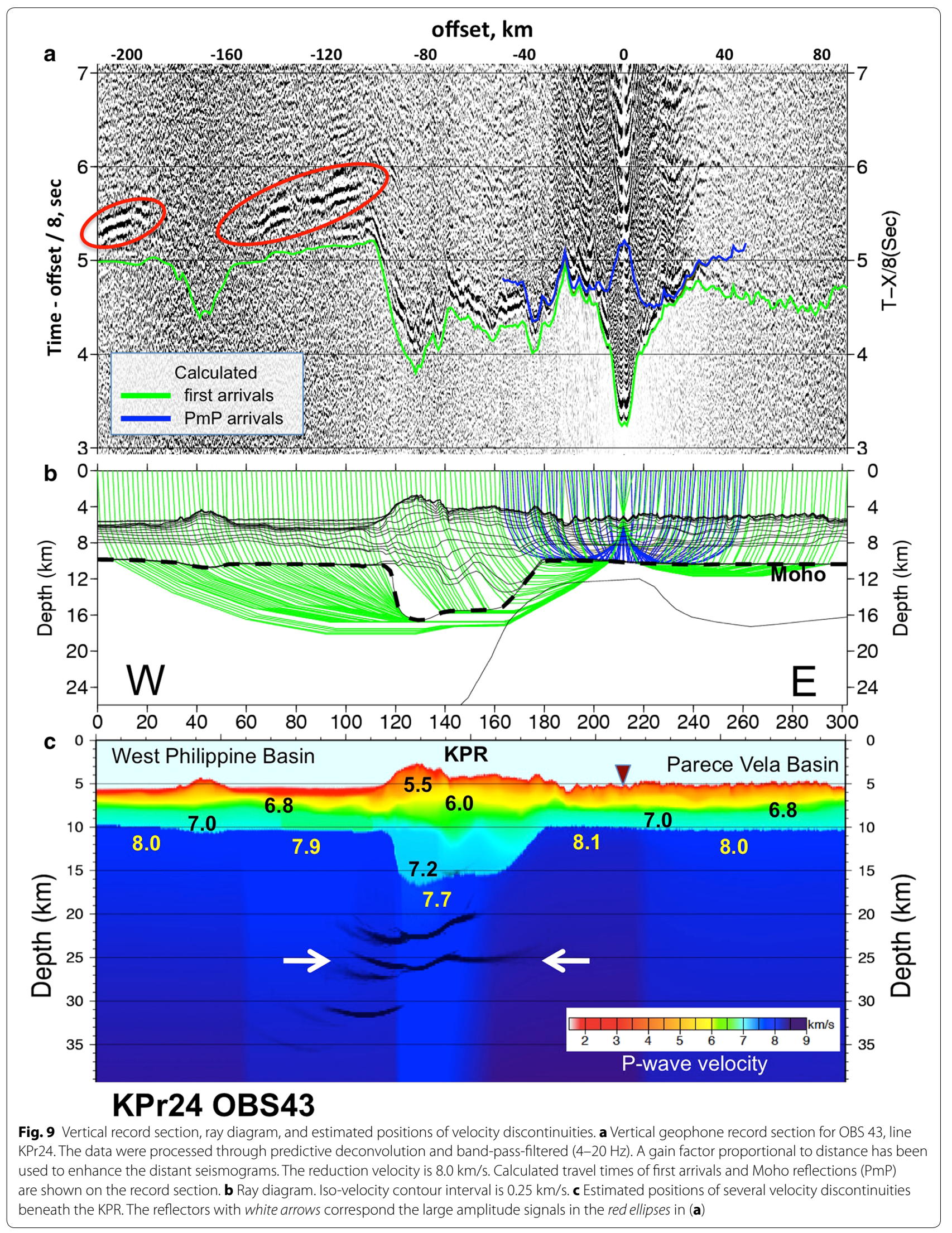




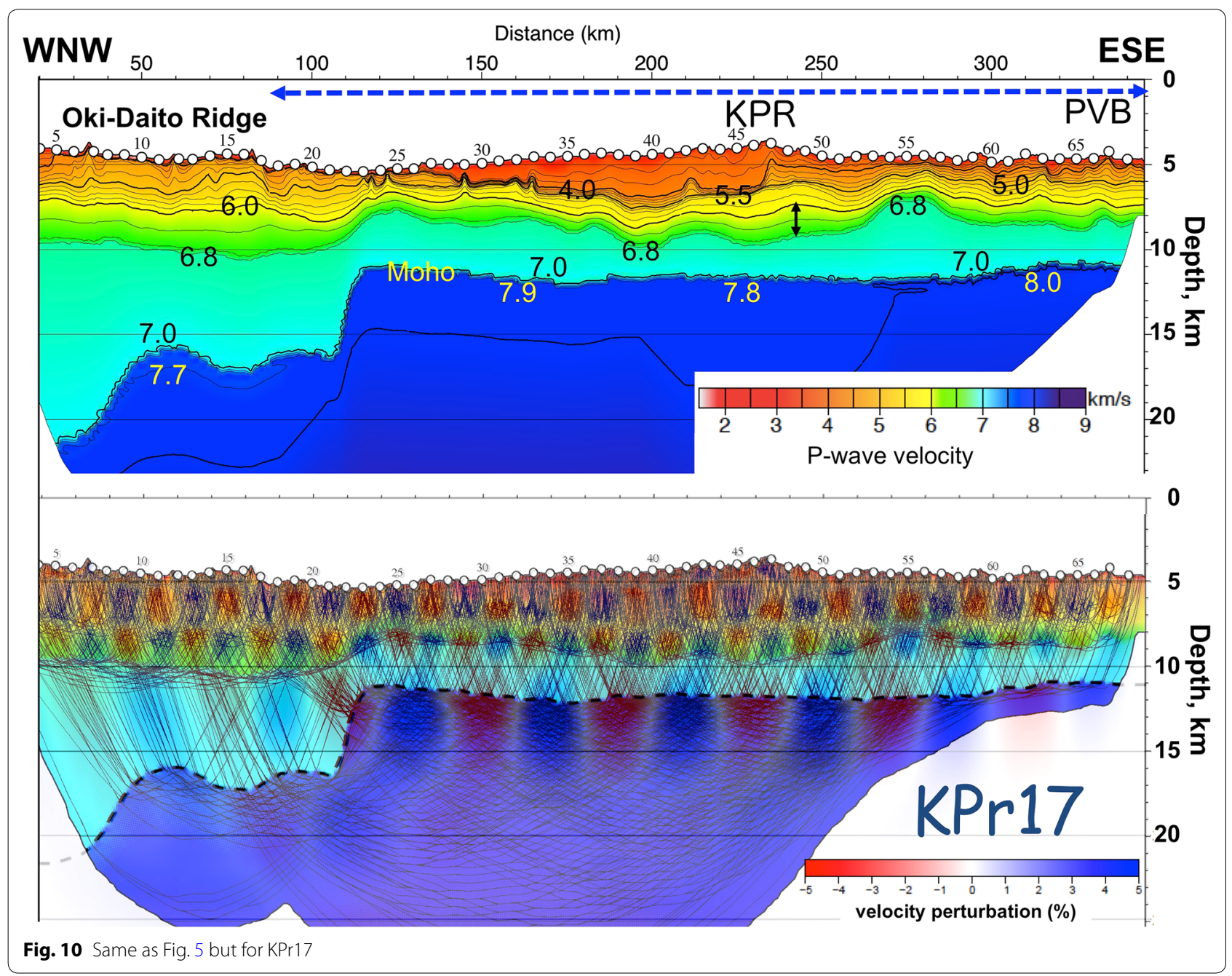

magnetic anomalies as suggested by Yamazaki and Yuasa (1998). Similar high magnetic anomalies are also distributed along the northern KPR (Yamazaki and Yuasa 1998), and KPr4 and SPr10 lines cross these anomalies which match the distinctive dipolar magnetic anomalies in Fig. 2 right. Our Vp models show that thick middle crust exists below both of the lines. A clear dipolar anomaly on the KPr19 (Fig. 2) also indicates thicker middle crust beneath Okinotori-shima Island.

\section{Along-ridge variation in Vp models of the KPR}

Figures 3 and 4 show that the KPR crust is roughly thicker than approximately $20 \mathrm{~km}$ in the north (Regions 1 and 2) with exceptions of KPr8, KPr7, and KPr31, than in the south (Regions 3, 4, and 5), although the maximum crustal thickness beneath the KPR varies with each profile. The crustal structure of the Izu-Ogasawara arc revealed a similar but clearer variation from north to south along the volcanic front (Kodaira et al. 2007b).
They showed large changes in the crustal thickness from 26 to $35 \mathrm{~km}$ beneath northern Izu arc to $9-22 \mathrm{~km}$ in the Ogasawara arc, assuming the Moho corresponds to the $7.6 \mathrm{~km} / \mathrm{s}$ velocity contour.

Only line KPr1 was acquired parallel to the ridge axis at the western part of the north KPR (Fig. 1). The Vp model (Fig. 3 top right) shows several bathymetric highs with thicker crust, distributed at an interval of $50-100 \mathrm{~km}$, which are subducting beneath the landward plate as reported by Nishizawa et al. (2009). Both the forward modeling and tomographic inversion support a large variation in Pn velocity along KPr1. Higher Pn velocities are obtained below the Kikai Basin and Amami-Sankaku Basin. The higher Pn velocities below the Amami-Sankaku Basin are also detected at KPr6 and KPr8 in Fig. 3. While the Pn velocities at the Kikai Basin varies from $7.7 \mathrm{~km} / \mathrm{s}$ at $\mathrm{KPr} 4$ to $8.1 \mathrm{~km} / \mathrm{s}$ at $\mathrm{SPr} 10$, such inhomogeneity may be related to the unknown tectonic evolution of these basins. 


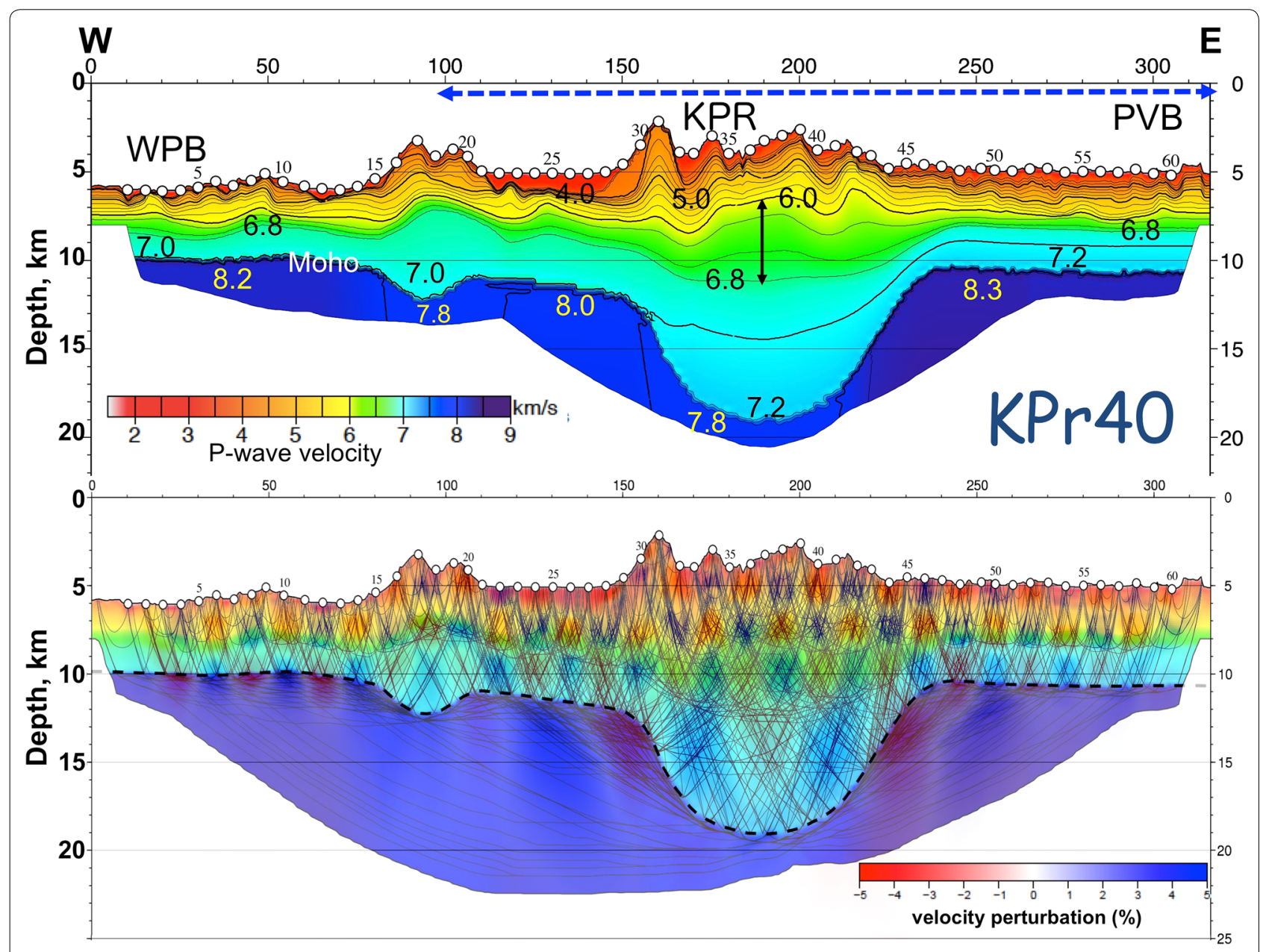

Fig. 11 Same as Fig. 5 but for KPr40

Transition between the KPR and the backarc basins on the east

The seafloor topography at the boundary between the KPR and the Shikoku or Parece Vela backarc basins is characterized by sharp and steep scarps supposed to be formed by the initial rifting, breakup, and early separation of the proto-arc. The sediment ponds identified by the multi-channel seismic profiles (e.g., KRr4 and KPr11 in Fig. 12) are also related to the rifting. The Vp models below the transition area are characterized by thinner crust with a thickness less than $4 \mathrm{~km}$ (Figs. 3, 4) and often slightly higher Pn velocity of $>8.0 \mathrm{~km} / \mathrm{s}$ compared with those of the Shikoku and Parece Vela Basins. This thinner crust and higher Pn velocity are considered as a result from the initial extension of the paleo-arc crust and upward migration of deeper mantle materials with higher Vp, respectively.

Although serpentinized mantle is sometimes formed near the base of the rifted crust along non-volcanic passive margins in the North Atlantic (e.g., Whitmarsh et al.
1996; Reid 1994), the Pn velocity of $>8.0 \mathrm{~km} / \mathrm{s}$ in our result does not indicate existence of serpentinized materials. Moreover, our preliminary analysis of S-wave travel times showed $\mathrm{Vp} / \mathrm{Vs}$ in the crust and uppermost mantle in the transition area was around 1.73 , significantly less than 1.8 , which is different from $\mathrm{Vp} / \mathrm{Vs}$ of serpentinized rocks. On the other hand, similar thin crust and high Pn velocities at the arc-basin transition are also found along western edge of the Izu-Ogasawara arc (Takahashi et al. 2009) and Mariana arc (Takahashi et al. 2007), the conjugate to the KPR before the separation of the proto-island arc. These features indicate that there was not water supply into the uppermost mantle at the rifting stage.

The seismic structure at the northern end of the eastern KPR transition is very important for locating the western limit of the future Nankai megathrust earthquake with a magnitude of around 9 (Cabinet Office of Japan 2012). There is an intrinsic difference in lithosphere thicknesses between the Shikoku Basin with an age less than 30 Ma (e.g., Okino et al. 1999) and the Daito Ridges 


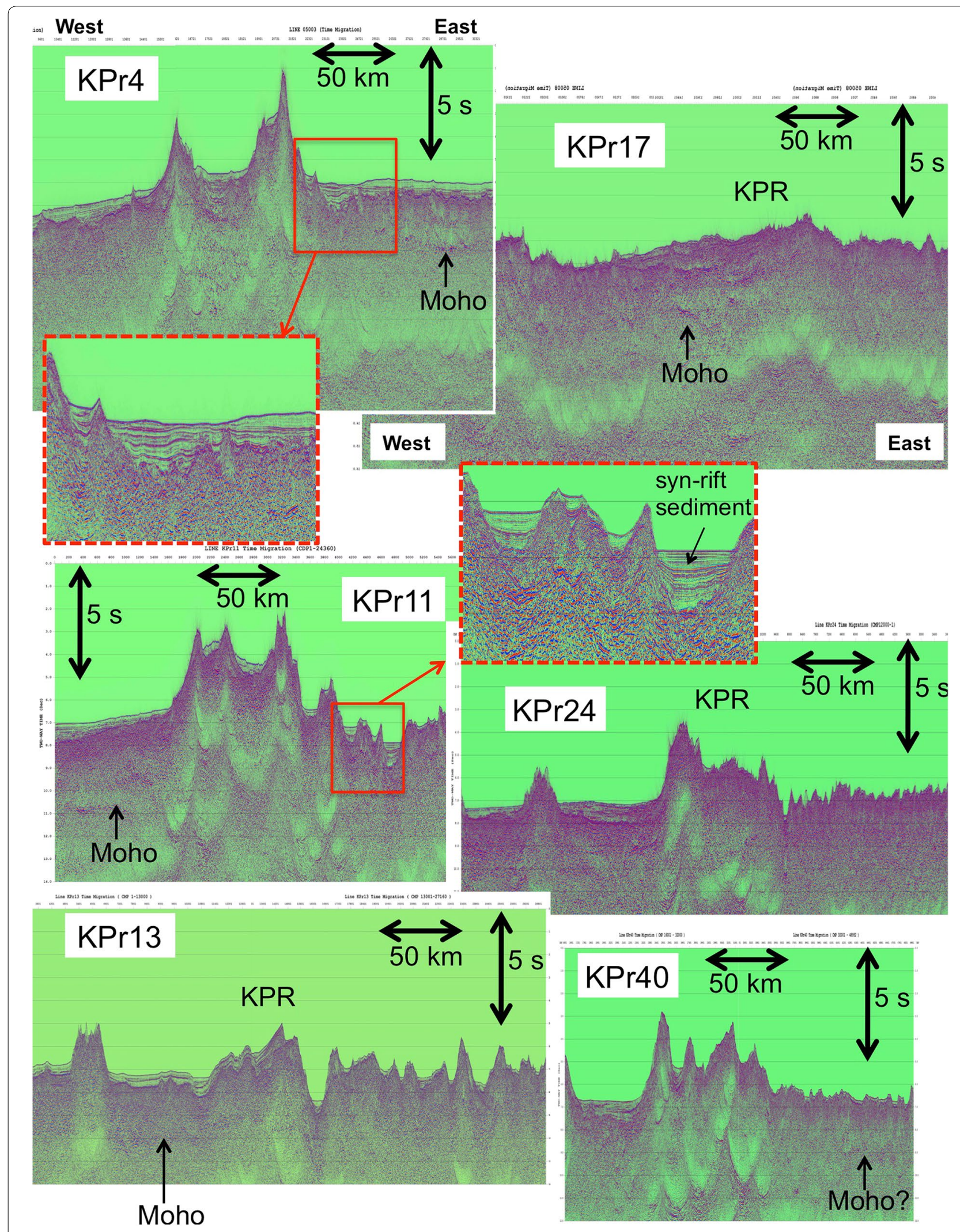

Fig. 12 Examples of the MCS records representative for each region. The areas in the red squares are enlarged in the dotted red squares for KPr4 and $\operatorname{KPr} 11$ 
of Cretaceous to Eocene age (Ishizuka and Yuasa 2007). Moreover, this study revealed the large discontinuity in crustal thicknesses between the thick crusts below the KPR and significantly thin crusts beneath the transition on the subducting Philippine Sea plate, which suggests the northernmost KPR transition could be a possible segment boundary in a future large earthquake at the Nankai Trough.

\section{Transition between the KPR and the western backarc basins or other structures}

Sedimentary aprons with thicknesses of around 1-2 km are commonly observed along the western slope of the KPR (Fig. 12), which indicates the sediments were deposited after KPR formation. However, in the deeper part, the crustal models of west of the KPR show large variations among the seismic lines as shown in Figs. 3 and 4. This is because the tectonic settings of the western side vary from north to south along the KPR, such as the Kikai and Amami-Sankaku Basins in Region 1, the Daito Ridge as a paleo-island arc and Minami-Daito Basins as intra-arc basins in Region 2, the Minami-Daito Basins and Mangetsu Basin in Region 3, the Oki-Daito Ridge as an island arc, the West Philippine Basin (WPB) as a backarc basin and the CBF Rift as the spreading center of the WPB in Region 4, and WPB in Region 5. Vp models for the Daito Ridges were already compiled by Nishizawa et al. (2014), and those for the several other basins will be published in another paper.

\section{Deep reflectors below the KPR}

We sometimes observed large amplitude reflection signals at far offsets in OBS record sections as shown in Fig. 9. These reflection signals are mapped to several reflectors at depths of $22-40 \mathrm{~km}$ below the seafloor of the KPR. The appearance of these reflection signals varies on each line, and it is very difficult to constrain the spatial distribution or continuity of these deep reflectors. These deep reflectors might be distributed discontinuously across the region.

Similar several deep reflectors are found below the southern Izu-Ogasawara arc at depths of around 25-35 km (Takahashi et al. 2009). Moreover, Takahashi et al. (2008) also observed upper mantle reflections at depths of 20 and $30 \mathrm{~km}$ beneath the western side of the West Mariana Ridge and from 30 to $35 \mathrm{~km}$ below the Mariana arc. In a petrological model for arc crust evolution of the IBM arc proposed by Tatsumi et al. (2008, 2015), a middle crust was produced from the basaltic initial arc crust, and then the restite with more mafic composition transfers to the mantle. Therefore, the origin of the upper mantle reflectors might be related to the transformation of the mafic/dense crustal materials due to repeated crustal growth, which is consistent with slower mantle Vp below the arc. Sato et al. (2009) inferred the distribution of a seismic reflector at depths of 20-40 km in the upper mantle below the volcanic front along the northern Izu-Ogasawara arc defines the base of the low $\mathrm{Vp}$ uppermost mantle composed of the restite and olivine cumulates.

\section{Conclusions}

We acquired 27 seismic lines to determine the P-wave velocity structure along the KPR. Our results show the following:

1. Although the crustal thickness below the KPR bathymetric high varies along the ridge axis, the northern KPR is generally thicker than the southern KPR. The KPR crust is significantly thicker than the adjacent backarc basin oceanic crusts to both the east and west. The thick crust is mainly due to a thickened lower crust, but especially thick crust $>20 \mathrm{~km}$ also has a thick middle crust. The uppermost mantle velocities beneath the KPR bathymetric high are less than $8.0 \mathrm{~km} / \mathrm{s}$ and sometimes accompanied by a slightly higher $\mathrm{Vp}$ of around $7.2 \mathrm{~km} / \mathrm{s}$ at the base of the crust. Deeper reflectors beneath the KPR Moho were often observed and might be distributed discontinuously and regionally. These above characteristics are also found in the Izu-Ogasawara intra-oceanic island arc, the conjugate arc to the KPR.

2. The eastern side of the KPR corresponds to the transition to the Shikoku and Parece Vela Basins. The Vp models show that the transition zone is characterized by a slightly higher Pn velocity and thinner crust elsewhere in the backarc basins, which may be a feature produced during the initial rifting stage of the protoIBM arc.

3. Thick sedimentary aprons are usually observed at the shallower part of the western slope of the KPR. The Vp models to the west of the KPR, however, vary depending on their regional tectonics.

In this paper, we have presented many seismic profiles using the large amount of the seismic data obtained from the Japanese CSS Project. However, some aspects of these data have not yet been analyzed, such as other reflections from crust and uppermost mantle, S-wave signals, etc. Further study including other geophysical and geological investigation is still required to construct and revise the Philippine Sea plate tectonic evolution models.

\section{Authors' contributions}

$\mathrm{AN}, \mathrm{KK}$, and $\mathrm{MO}$ contributed to the analysis and interpretation of the seismic data. AN compiled the regional tectonic information and drafted the manuscript. All authors read and approved the final manuscript. 


\section{Acknowledgements}

The authors gratefully acknowledge Prof. Emeritus J. Kasahara, and ex-members of Continental Shelf Surveys Co. Ltd., for data processing and analyses. Y. Katagiri and N. Watanabe and the members of the Continental Shelf Surveys Office, Hydrographic and Oceanographic Department, JCG, are thanked for the management of the seismic surveys. The manuscript benefited from constructive reviews and suggestions by anonymous reviewers and the editor Prof. T. Yamazaki. Careful English editing by the reviewer was very helpful. Most of the figures in this paper were produced using the GMT graphic package of Wessel and Smith (1998).

\section{Competing interests}

The authors declare that they have no competing interests.

Received: 10 August 2015 Accepted: 7 January 2016

Published online: 26 February 2016

\section{References}

Arisaka M, Shinohara M, Yamada T, Mochizuki K, Kaiho Y, Araki E, Nakahigashi K, Ito M, Shiobara H, Suyehiro K, Kanazawa T (2003) Seismic structure of uppermost mantle and crust beneath West Philippine Basin and KyushuPalau Ridge by seafloor borehole seismometer and airgun experiment. Eos Trans Am Geophys Union 84(S31):F-0824

Cabinet Office of Japan (2012) Anticipated damages due to the Nankai Trough mega-thrust earthquake (second report). http://www.bousai.go.jp/jishin/ nankai/taisaku/pdf/1_1.pdf website Accessed 13 July 2015

Calvert AJ (2011) The seismic structure of island arc crust. In: Brown D, Ryan PD (eds) Arc-continent collision Frontiers in Earth sciences. Springer, Heidelberg, pp 87-119. doi:10.1007/978-3-540-88558-0 4

Fujie G, Kasahara J, Sato T, Mochizuki K (2000) Traveltime and raypath computation: a new method in a heterogeneous medium. J Soc Explor Geophys Jpn 53:1-11

Fujie G, Ito A, Kodaira S, Takahashi N, Kaneda Y (2006) Confirming sharp bending of the Pacific plate in the northern Japan trench subduction zone by applying a traveltime mapping method. Phys Earth Planet Inter 157:72-85. doi:10.1016/j.pepi.2006.03.013

Haraguchi S, Ishii T, Kimura Jl, Ohara Y (2003) Formation of tonalite from basaltic magma at the Komahashi-Daini Seamount, northern KyushuPalau Ridge in the Philippine Sea, and growth of Izu-Ogasawara (Bonin)Mariana arc crust. Contrib Mineral Petrol 145:151-168. doi:10.1007/ s00410-002-0433-y145:151-68

Ishihara T, Koda K (2007) Variation of crustal thickness in the Philippine Sea deduced from three-dimensional gravity modeling. Island Arc 16:322-337

Ishizuka O, Yuasa M (2007) Age and geochemical characteristics of the igneous rocks recovered the Philippine Sea and Ogasawara Plateau area as a part of basic researches on exploration technologies for deep-sea natural resources. Rep on Deep Sea Survey Technology for Natural Resources in Japan, JOGMEC, Tokyo, pp 255-296

Ishizuka O, Taylor RN, Yuasa M, Ohara Y (2011) Making and breaking an island arc: a new perspective from the Oligocene Kyushu-Palau arc, Philippine Sea. Geochem Geophys Geosyst 12:Q05005. doi:10.1029/2010GC003440

Ishizuka O, Taylor RN, Ohara Y, Yuasa M (2013) Upwelling rifting and ageprogressive magmatism from the Oki-Daito mantle plume. Geology 41(9):1011-1014. doi:10.1130/G34525.1

Kaneda K, Nishizawa A, Oikawa M (2015) Large-Scale seismic experiments conducted by Japan Coast Guard in the northwestern Pacific plate and the Philippine Sea plate. J Geogr 124(5):787-811 (in Japanese with English abstract)

Kodaira S, Sato T, Takahashi N, Miura S, Ito A, Tamura Y, Tatsumi Y, Kaneda Y (2007a) Seismological evidence for variable growth of crust along the Izu intraoceanic arc. J Geophys Res 112:B05104. doi:10.1029/2006JB004593

Kodaira S, Sato T, Takahashi N, Miura S, Tamura Y, Tatsumi Y, Kaneda Y (2007b) New seismological constraints on growth of continental crust in the IzuBonin intra-oceanic arc. Geology 35:1031-1034. doi:10.1130/G23901A.1

Kodaira S, Sato T, Takahashi N, Yamashita M, No T, Kaneda Y (2008) Seismic imaging of a possible paleo-arc in the Izu-Bonin intra-oceanic arc and its implications for arc evolution processes. Geochem Geophys Geosyst. doi: 10.1029/2008GC002073

Korenaga J, Holbrook WS, Kent GM, Kelemen PB, Detrick RS, Larsen HC, Hopper JR, Dahl-Jensen T (2000) Crustal structure of the southeast Greenland margin from joint refraction and reflection seismic tomography. J Geophys Res 105:21591-21614. doi:10.1029/2000JB900188

Kubota R, Nishiyama E, Murase K, Kasahara J (2009) Traveltime estimation of first arrivals and later phases using the modified graph method for a crustal structure analysis. Explor Geophys 40:105-113

Larsen SC, Schultz CA (1995) ELAS3D: 2D/3D elastic finite-difference wave propagation code. Lawrence Livermore National Laboratory technical report no. UCRL-MA-121792, pp 19

Mrozowski CL, Hayes DE (1979) The evolution of the Parece Vela Basin, eastern Philippine Sea. Earth Planet Sci Lett 46:49-67

Murauchi S, Den N, Asano S, Hotta H, Yoshii T, Asanuma T, Hagiwara K, Ichikawa K, Sato T, Ludwig WJ, Ewing Jl, Edgar NT, Houtz RE (1968) Crustal structure of the Philippine Sea. J Geophys Res 73:3143-3171

Nishizawa A, Kaneda K, Nakanishi A, Takahashi N, Kodaira S (2006) Crustal structure of the ocean-island arc transition at the mid Izu-Ogasawara (Bonin) arc margin. Earth Planets Space 58:e33-e36

Nishizawa A, Kaneda K, Katagiri Y, Kasahara J (2007) Variation in crustal structure along the Kyushu-Palau Ridge at 15-21 N on the Philippine Sea plate based on seismic refraction profile. Earth Planets Space 59:e17-e20

Nishizawa A, Kaneda K, Oikawa M (2009) Seismic structure of the northern end of the Ryukyu Trench subduction zone, southeast of Kyushu, Japan. Earth Planets Space 61:e37-e40

Nishizawa A, Kaneda K, Oikawa M (2011) Backarc basin oceanic crust and uppermost mantle seismic velocity structure of the Shikoku Basin, south of Japan. Earth Planets Space 63:151-155

Nishizawa A, Kaneda K, Katagiri Y, Oikawa M (2014) Wide-angle refraction experiments in the Daito Ridges region at the northwestern end of the Philippine Sea plate. Earth Planets Space 66:25

Oikawa M, Kaneda K (2007) Bouguer gravity anomaly in the Western Pacific Tech Bull Hydrogr Oceanogr 25:96-99 (in Japanese with English abstract)

Okino K, Shimakawa Y, Nagaoka Y (1994) Evolution of the Shikoku Basin. J Geomag Geoelectr 46:463-479

Okino K, Ohara Y, Kasuga S, Kato Y (1999) The Philippine Sea: new survey results reveal the structure and the history of the marginal basins. Geophys Res Lett 26:2287-2290

Oshida A, Kubota R, Nishiyama E, Ando J, Kasahara J, Nishizawa A, Kaneda K (2008) A new method for determining OBS positions for crustal structure studies, using airgun shots and precise bathymetric data. Explor Geophys 39:15-25

Reid ID (1994) Crustal structure of a nonvolcanic rifted margin east of Newfoundland. J Geophys Res 99(B8):15161-15180. doi:10.1029/94JB00935

Sasaki T, Yamazaki T, Ishizuka O (2014) A revised spreading model of the West Philippine Basin. Earth Planets Space 66:83. doi:10.1 186/1880-5981-66-83

Sato T, Kodaira S, Takahashi N, Tatsumi Y, Kaneda Y (2009) Amplitude modeling of the seismic reflectors in the crust-mantle transition layer beneath the volcanic front along the northern Izu-Bonin island arc. Geochem Geophys Geosys. doi:10.1029/2008GC001990

Seno T, Maruyama S (1984) Paleogeographic reconstruction and origin of the Philippine Sea. Tectonophysics 102:53-84

Shinohara M, Takahashi N, Li K, Suyehiro K, Taira A (1999) Crustal structure of the northern Izu-Bonin arc and Kyushu-Palau Ridge by controlled-source seismology. Mon Earth 23:67-78 (in Japanese)

Suyehiro K, Takahashi N, Ariie Y, Yokoi Y, Hino H, Shinohara M, Kanazawa T, Hirata N, Tokuyama H, Taira A (1996) Continental crust, crustal underplating, and low-Q upper mantle beneath an oceanic island arc. Science 272:390-392

Takahashi N, Kodaira S, Klemperer S, Tatsumi Y, Kaneda Y, Suyehiro K (2007) Crustal structure and evolution of the Mariana intra-oceanic island arc Geology 35:203-206

Takahashi N, Kodaira S, Tatsumi Y, Kaneda Y, Suyehiro K (2008) Structure and growth of the Izu-Bonin-Mariana arc crust: 1. Seismic constraint on crust and mantle structure of the Mariana arc-back-arc system. J Geophys Res 113:B01104. doi:10.1029/2007JB005120

Takahashi N, Kodaira S, Tatsumi Y, Yamashita M, Sato T, Kaiho Y, Miura S, No T, Takizawa K, Kaneda Y (2009) Structural variations of arc crusts and rifted 
margins in the southern Izu-Ogasawara arc-back arc system. Geochem Geophys Geosyst 10:Q09X08. doi:10.1029/2008GC002146

Tatsumi Y, Shukuno H, Tani K, Takahashi N, Kodaira S, Kogiso T (2008) Structure and growth of the Izu-Bonin-Mariana arc crust: 2. Role of crust-mantle transformation and the transparent Moho in arc crust evolution. J Geophys Res 113:B02203. doi:10.1029/2007JB005121

Tatsumi Y, Sato T, Kodaira S (2015) Evolution of the Earth as an andesite planet: water, plate tectonics, and delamination of anti-continent. Earth Planets Space 67:91. doi:10.1186/s40623-015-0267-2

Tokuyama H (2007) Tectonic development and reconstruction of Philippine Sea Plate since late Cretaceous. Report on Deep Sea Survey Technology for Natural Resources in Japan, JOGMEC, Tokyo, pp 430-456
Wessel P, Smith WHF (1998) New, improved version of the generic mapping tools released. EOS Trans AGU 79:579

White RS, McKenzie D, O'Nions RK (1992) Oceanic crustal thickness from seismic measurements and rare earth element inversions. J Geophys Res 97:19683-19715

Whitmarsh RB, White RS, Horsefield SJ, Sibuet J-C, Recq M, Louvel V (1996) The ocean-continent boundary off the western continental margin of Iberia: crustal structure west of Galicia Bank. J Geophys Res 101(B12):2829128314. doi:10.1029/96JB02579

Yamazaki T, Yuasa M (1998) Possible Miocene rifting of the Izu-Ogasawara (Bonin) arc deduced from magnetic anomalies. Island Arc 7:374-382

\section{Submit your manuscript to a SpringerOpen ${ }^{\odot}$ journal and benefit from:}

- Convenient online submission

- Rigorous peer review

- Immediate publication on acceptance

- Open access: articles freely available online

- High visibility within the field

- Retaining the copyright to your article

Submit your next manuscript at $>$ springeropen.com 